\title{
PENERAPAN MODEL MASTERY LEARNING BERBANTUAN LKPD UNTUK MENINGKATKAN HASIL BELAJAR MATEMATIKA PESERTA DIDIK DI KELAS VIII.3 SMP NEGERI 4 KOTA BENGKULU
}

\author{
${ }^{1}$ Rika Novelia, ${ }^{2}$ Dewi Rahimah, ${ }^{3}$ M. Fachruddin $S$ \\ 1,2,3 Prodi Pendidikan Matematika JPMIPA FKIP Universitas Bengkulu \\ Email: ${ }^{1}$ rikanovelia13@gmail.com, ${ }^{2}$ rahimah_dewi@yahoo.com, ${ }^{3}$ mfachruddin.s@gmail.com
}

\begin{abstract}
Abstrak
Penelitian ini bertujuan untuk mengetahui cara menerapkan model Mastery Learning berbantuan LKPD dapat meningkatkan aktivitas dan hasil belajar peserta didik. Penelitian ini merupakan Penelitian Tindakan Kelas dengan tehnik pengumpulan data melalui lembar observasi aktivitas dan tes hasil belajar peserta didik. Subjek dalam penelitian adalah Kelas VIII.3 SMP Negeri 4 Kota Bengkulu tahun ajaran 2016/2017 yang berjumlah 35 peserta didik. Hasil penelitian menunjukkan bahwa penerapan model Mastery Learning berbantuan LKPD dapat meningkatkan hasil belajar peserta didik dengan cara mengaitkan materi pembelajaran dengan kehidupan sehari-hari, memotivasi peserta didik untuk bertanya, serta membimbing dalam mengerjakan latihan soal. Peningkatan hasil belajar dilihat dari nilai rata-rata peserta didik pada siklus I sampai siklus III yaitu pada siklus I adalah 66,21 dengan persentase ketuntasan belajar $42,86 \%$; pada siklus II yaitu 79,14 dengan persentase ketuntasan belajar 68,57\%; dan pada siklus III yaitu 89,50 dengan persentase ketuntasan belajar 91,43\%.
\end{abstract}

Kata Kunci: Hasil Belajar, LKPD, Mastery Learning.

\begin{abstract}
This research aims to find out how to apply the Mastery Learning model assisted LKPD can improve the activity and student's learning outcomes. This research was a classroom action research with data collection technique through observation sheet of student's activity and test of student's learning result. The subjects of this research were Class VIII.3 SMP Negeri 4 Kota Bengkulu academic year 2016/2017 which amounted to 35 students. The results showed the application of Mastery Learning model assisted LKPD can improve the students learning outcomes by linking the learning material with the daily life, motivating to ask questions, as well as guide in doing the exercise questions. Improved learning outcomes can be seen from the average value of students in the cycle I to cycle III that is in the cycle I 66,21 with the percentage of learning completeness that is $42.86 \%$; in the cycle II 79,14 with the percentage of learning completeness that is 68.57\%; and in the cycle III 89,50 with the percentage of learning completeness that is $91.43 \%$.
\end{abstract}

Keywords: Learning Outcomes, LKPD, Mastery Learning.

\section{PENDAHULUAN}

Matematika merupakan salah satu pelajaran yang sangat penting diberikan di sekolah. Matematika sangat diperlukan baik untuk kehidupan sehari-hari maupun dalam menghadapi kemajuan IPTEK sehingga matematika perlu dibekalkan kepada setiap peserta didik sejak SD, bahkan sejak TK (Hudojo, 2005: 35). Penguasaan matematika yang baik dapat dilihat dari hasil belajar matematika yang baik pula saat belajar di sekolah.
Proses belajar mengajar matematika yang berlangsung di sekolah secara umum menyebabkan peserta didik mengalami kendala dalam penguasaan materi. Salah satu penyebabnya adalah pengelolaan kelas sehingga tidak semua peserta didik memperoleh nilai diatas nilai KKM. Matematika dianggap pelajaran yang sulit dipahami dan diaplikasikan kedalam kehidupan sehari-hari karena obyeknya yang abstrak, membutuhkan penalaran, dan berpola pikir deduktif, sehingga peserta didik kurang tertarik, 
kurang antusias, serta rasa ingin tahu peserta didik cukup rendah dalam mengikuti pelajaran matematika jika hanya disajikan untuk menghafal rumus-rumus. Akibatnya, peserta didik cenderung menghafal dan materi yang diajarkan tidak dapat dipahami dengan baik.

Berdasarkan data yang diperoleh dari hasil wawancara dengan guru matematika Kelas VIII.3 SMP Negeri 4 Kota Bengkulu, masih terdapat peserta didik yang kurang tertarik dan kurang antusias mengikuti pelajaran matematika sehingga menyebabkan hasil belajar rendah. Interaksi yang terjadi dalam kelas masih didominasi oleh peserta didik yang mempunyai kemampuan lebih. Akibatnya tidak semua peserta didik menguasai materi yang diberikan dengan baik.

Pembelajaran di kelas kurang memperhatikan ketuntasan belajar secara individual dalam menguasai materi dibuktikan dengan nilai ulangan harian yang diperoleh peserta didik bervariasi. Dengan demikian, salah satu model pembelajaran yang dapat diterapkan untuk mengatasi hal tersebut adalah belajar tuntas (mastery learning). Menurut Mulyasa (2009: 237) belajar tuntas berasumsi bahwa di dalam kondisi yang tepat semua peserta didik mampu belajar dengan baik dan memperoleh hasil yang maksimal terhadap seluruh materi yang dipelajari.

Salah satu bahan ajar yang dapat digunakan agar peserta didik antusias dalam proses pembelajaran melalui kegiatan diskusi dan bekerja sama dengan teman kelompok serta saling bertukar pendapat adalah dengan menggunakan Lembar Kerja Peserta Didik (LKPD). LKPD adalah lembar-lembar yang berisi tugas yang harus dikerjakan peserta didik untuk menguasi kompetensi yang dipersyaratkan (Sulastri, 2014: 13). LKPD dapat dijadikan pedoman agar peserta didik dapat melakukan kegiatan pembelajaran secara aktif dan mandiri. Dengan demikian penerapan model Mastery Learning berbantuan LKPD diharapkan dapat meningkatkan hasil belajar matematika peserta didik.

Berdasarkan latar belakang masalah, maka rumusan masalah dalam penelitian ini adalah "Bagaimana penerapan model Mastery Learning berbantuan LKPD dapat meningkatkan hasil belajar matematika peserta didik di Kelas VIII.3 SMP Negeri 4 Kota Bengkulu?".

Sesuai dengan rumusan masalah yang ada, maka tujuan yang hendak dicapai dalam penelitian ini adalah "Untuk mengetahui cara menerapkan model Mastery Learning berbantuan LKPD dapat meningkatkan hasil belajar matematika peserta didik di Kelas VIII.3 SMP Negeri 4 Kota Bengkulu".

\section{Hasil Belajar}

Kegiatan akhir dalam proses pembelajaran adalah evaluasi yang bertujuan untuk mengetahui hasil belajar yang telah dilakukan. Menurut Dimyati dan Mudjiono (2006: 3) dengan berakhirnya suatu proses belajar, maka peserta didik memperoleh hasil belajar yang merupakan hasil dari interaksi tindak belajar dan tindak mengajar.

Hasil belajar peserta didik pada hakikatnya adalah perubahan tingkah laku yang mencakup bidang kognitif, afektif, dan psikomotoris. Jadi, dalam kegiatan pembelajaran tidak hanya aspek kognitif (pengetahuan) saja yang diperhatikan, tetapi juga aspek afektif (sikap) dan psikomotor (keterampilan) (Sudjana, 2011: 3).

Berdasarkan beberapa pendapat di atas, peneliti menyimpulkan bahwa hasil belajar adalah perubahan tingkah laku atau kemampuan yang diperoleh pada diri peserta didik dalam aspek kognitif (pengetahuan) melalui penilaian tes hasil belajar.

\section{Belajar Tuntas (Mastery Learning)}

Belajar tuntas berasumsi bahwa di dalam kondisi yang tepat semua peserta didik mampu belajar dengan baik, dan memperoleh hasil yang maksimal terhadap seluruh materi yang dipelajari (Mulyasa, 2009: 237). Sejalan dengan pendapat tersebut, Surjadi (2012: 152) menyatakan bahwa dengan menerapkan model belajar tuntas, peserta didik mampu belajar dengan baik dan memperoleh hasil maksimal, sehingga dalam proses pembelajaran peserta didik perlu mendapat bimbingan untuk menyertai tujuan belajar. Jadi, setiap peserta didik akan mampu menguasai seluruh materi pembelajaran dengan kemampuan pemahaman yang dimiliki dan dengan model pembelajaran 
yang tepat, salah satunya dengan menerapkan Mastery Learning.

Model Belajar Tuntas (Mastery Learning) dikembangkan oleh John B. Caroll (1971) dan Benjamin Bloom (1971). Adapun penerapan model Mastery Learning berbantuan LKPD dilaksanakan dengan langkah-langkah pembelajaran sebagai berikut (Wena, 2009: 184-185):

a. Orientasi (orientation)

Guru menjelaskan tahapan pembelajaran dan tugas yang akan dikerjakan selama proses pembelajaran berlangsung, serta menggali pengetahuan awal perserta didik terhadap materi.

b. Penyajian (presentation)

Peserta didik bekerja sama dalam kelompoknya yang beranggotakan empat atau lima orang untuk mendiskusikan materi pembelajaran yang disajikan dalam LKPD.

c. Latihan terstruktur (structured practice)

Peserta didik mengerjakan soal latihan terstruktur (dengan langkah-langkah penyelesaian soal secara bertahap) kepada setiap peserta didik dengan waktu pengerjaan soal yang telah ditentukan.

d. Latihan terbimbing (guided practice)

Peserta didik mengerjakan soal latihan yang diberikan dengan bimbingan guru.

e. Latihan mandiri (independent practice)

Peserta didik diberikan tugas atau latihan soal yang dikerjakan secara mandiri tanpa bimbingan guru. Kegiatan ini dapat dikerjakan di kelas atau berupa pekerjaan rumah.

\section{Lembar Kerja Peserta Didik (LKPD)}

Terdapat dua istilah lembar kerja sebagai bahan ajar cetak yang digunakan dalam pembelajaran yaitu LKS dan LKPD. Pada dasarnya LKS dan LKPD memilki pengertian yang sama. Lembar Kerja Siswa (student work sheet) adalah lembaran-lembaran berisi tugas yang harus dikerjakan oleh peserta didik (Depdiknas, 2008: 23). Sedangkan Bahan ajar cetak LKPD adalah lembar-lembar yang berisi tugas yang harus dikerjakan peserta didik untuk menguasi kompetensi yang dipersyaratkan (Sulastri, 2014: 13). Karena penelitian ini akan dilaksanakan di sekolah yang menerapkan kurikulum 2013 maka Lembar Kerja Siswa (LKS) penulis sebut sebagai Lembar Kerja Peserta Didik (LKPD).

Menurut Trianto (2011: 222-223) LKPD adalah panduan peserta didik yang digunakan untuk melakukan kegiatan penyelidikan atau pemecahan masalah. LKPD memuat kegiatan disertai petunjuk serta langkah-langkah yang harus dilakukan oleh peserta didik dalam menyelesaikan tugas yang diberikan untuk memaksimalkan pemahaman dan mencapai indikator pencapaian hasil belajar. Lembar kegiatan biasanya berupa petunjuk, langkahlangkah untuk menyelesaikan suatu tugas (Majid, 2012: 176).

Sebagai salah satu bahan ajar yang dapat digunakan dalam memudahkan proses belajar mengajar di sekolah, LKPD yang dibuat oleh guru tentu memiliki fungsi dan tujuan. Menurut Prastowo (2013: 205-206) LKPD mempunyai empat fungsi, yaitu: (1) sebagai bahan ajar yang bisa meminimalkan peran pendidik, namun lebih mengaktifkan peserta didik, (2) sebagai bahan ajar yang mempermudah peserta didik untuk memahami materi yang diberikan, (3) sebagai bahan ajar yang ringkas dan kaya tugas untuk berlatih, dan (4) memudahkan pelaksanaan pengajaran kepada peserta didik.

Selain itu, Prastowo (2013: 206) juga menambahkan bahwa paling tidak ada empat poin yang menjadi tujuan penyusunan LKPD, yaitu: (1) menyajikan bahan ajar yang memudahkan peserta didik untuk berinteraksi dengan materi yang diberikan, (2) menyajikan tugas-tugas yang meningkatkan penguasaan peserta didik terhadap materi yang diberikan, (3) melatih kemandirian belajar peserta didik, dan (4) memudahkan pendidik dalam memberikan tugas kepada peserta didik.

\section{METODE}

Jenis penelitian ini adalah Penelitian Tindakan Kelas (PTK). Menurut Kunandar (2011: 46) Penelitian Tindakan Kelas (PTK) adalah suatu kegiatan yang dilakukan guru di kelasnya sendiri dengan cara merencanakan, melaksanakan, mengamati, dan merefleksikan tindakan melalui beberapa siklus secara kolaboratif dan partisipatif yang bertujuan untuk memperbaiki atau meningkatkan mutu 
proses pembelajaran di kelasnya. PTK terdiri dari empat kegiatan yang dilakukan dalam siklus berulang. Tahapan PTK menurut Maharani (2014: 87-89) yaitu perencanaan, pelaksanaan, pengamatan, dan refleksi. Subjek dalam penelitian ini yaitu peserta didik Kelas VIII.3 SMP Negeri 4 Kota Bengkulu yang berjumlah 35 peserta didik yang terdiri dari 16 laki- laki dan 19 perempuan.

Instrumen yang digunakan dalam penelitian ini adalah tes hasil belajar yang dilakukan setiap akhir siklus. Sedangkan analisis data dalam penelitian ini data kuantitatif berupa nilai tes hasil belajar peserta didik.

Nilai tes hasil belajar peserta didik diperoleh dari tes akhir setiap siklus. Untuk mengetahui peningkatan hasil belajar, analisis dilakukan dengan menggunakan nilai rata-rata dan ketuntasan belajar klasikal peserta didik. Rumus yang digunakan untuk menghitung nilai rata-rata peserta didik dari Sudjana (2011: 109) yaitu:

Keterangan:

$$
\bar{X}=\frac{\sum X}{N}
$$

$\bar{X} \quad=$ Nilai rata-rata

$\sum X \quad=$ Jumlah semua nilai peserta didik

$N \quad=$ Banyak peserta didik

Hasil belajar peserta didik dikatakan meningkat dan tuntas (ketuntasan belajar klasikal) jika dalam kelas tersebut terdapat $>80 \%$ peserta didik yang memperoleh nilai diatas nilai Kriteria Ketuntasan Minimal (KKM) yaitu 75. Untuk menghitung persentase ketuntasan belajar digunakan rumus dari Aqib (2014: 41) yaitu:

$$
P=\frac{\text { Speserta didik yang tuntas belajar }}{\sum \text { peserta didik }} \times 100 \%
$$

Keterangan:

$P=$ Ketuntasan belajar

\section{HASIL DAN PEMBAHASAN}

Penelitian tindakan kelas dengan penerapkan model Mastery Learning berbantuan LKPD untuk meningkatkan hasil belajar peserta didik di Kelas VIII.3 SMP
Negeri 4 Kota Bengkulu dilaksanakan dalam 3 siklus.

Berdasarkan hasil perhitungan pada lembar tes siklus yang dilaksanakan setiap akhir siklus mengalami peningkatan seperti pada Tabel 1 berikut:

Tabel 1. Hasil Belajar Peserta Didik Setiap Siklus

\begin{tabular}{|c|c|c|c|}
\hline Siklus & $\begin{array}{c}\text { Nilai } \\
\text { rata- } \\
\text { rata }\end{array}$ & $\begin{array}{c}\text { Ketuntasan } \\
\text { belajar } \\
\text { klasikal }\end{array}$ & Keterangan \\
\hline I & 66,21 & $42,86 \%$ & $\begin{array}{c}\text { Belum } \\
\text { Tuntas }\end{array}$ \\
\hline II & 79,14 & $68,57 \%$ & $\begin{array}{c}\text { Belum } \\
\text { Tuntas }\end{array}$ \\
\hline III & 89,50 & $91,43 \%$ & Tuntas \\
\hline
\end{tabular}

Berdasarkan tabel 4 diatas dapat dilihat bahwa hasil belajar peserta didik mengalami peningkatan pada setiap siklus. Berdasarkan nilai tes hasil belajar pada siklus I diperoleh data nilai peserta didik dengan nilai tertinggi yaitu 95 dan nilai terendah yaitu 40 . Nilai ratarata tes hasil belajar yang diperoleh dari 35 peserta didik yang mengikuti tes siklus I adalah 66,21 dengan persentase ketuntasan belajar klasikal adalah $42,86 \%$. Hasil tes siklus tersebut masih sangat jauh dari kriteria keberhasilan pelaksanaan tindakan. Hal ini lah yang membuat nilai rata-rata tes siklus I peserta didik rendah dan termasuk dalam kategori belum tuntas.

Pada siklus I peserta didik hanya tau dan paham saja bagaimana cara menghitung luas permukaan bangun ruang sisi datar. Tetapi belum sampai pada kemampuan penerapan materi untuk menyelesaikan soal yang berkaitan dengan luas permukaan bangun ruang sisi datar dalam kehidupan sehari-hari. Peserta didik baru mampu mengingat materi dalam bentuk seperti yang diajarkan, dan mereka belum bisa menggunakan prosedur dalam menyelesaikan soal. Serta menganalisis perintah soal untuk mendapat solusi mencari luas permukaan bangun ruang sisi datar. Oleh karena itu peneliti memberikan tindakan yang dilaksanakan pada siklus II yaitu memotivasi peserta didik untuk membaca dan memahami perintah soal terlebih dahulu. Mengingatkan 
peserta didik untuk menulis keterangan diketahui dan ditanya pada jawaban soal karena hal itu juga memberikan poin terhadap nilai yang diperoleh peserta didik dalam latihan soal setiap pertemuan termasuk soal tes siklus. Selain itu guru memberikan bimbingan kepada peserta didik yang nilainya belum tuntas agar pada siklus berikutnya ketuntasan belajar peserta didik dapat meningkat dengan rata-rata nilai tes diatas nilai KKM.

Pada siklus II diperoleh data nilai peserta didik dengan nilai tertinggi yaitu 100 dan nilai terendah yaitu 40. Pada tes siklus II nilai ratarata peserta didik mencapai nilai KKM yaitu 75 , akan tetapi ketuntasan belajar peserta didik belum memenuhi indikator keberhasil penelitian karena belum mencapai $80 \%$. Sehingga masih dibutuhkan perbaikan tindakan pada siklus berikutnya agar peserta didik dapat belajar secara tuntas.

Penilaian selanjutnya dilakukan pada tes siklus III. Pada tes siklus III hasil belajar peserta didik juga mengalami peningkatan dibandingkan nilai tes siklus sebelumnya. Hal ini dikarenakan dalam menaksir luas dan volume bangun ruang tidak beraturan menggunakan benda-benda yang dapat ditemukan dalam kehidupan sehari-hari. Jika dibandingkan dengan alat peraga yang ada pada siklus sebelumnya, alat peraga pada siklus III meliputi luas dan volume bangun ruang tidak beraturan serta peluang teoritik lebih mudah dipahami dan diingat. Selain itu alat peraga yang dgunakan hampir mirip dengan yang ada pada soal tes yang diberikan sehingga peserta didik lebih mudah dalam menerapkan materi pembelajaran yang diberikan untuk menjawab soal tes siklus II tersebut.

Berdasarkan nilai tes hasil belajar pada siklus III diperoleh data nilai peserta didik dengan nilai tertinggi yaitu 100 dan nilai terendah yaitu 70. Salah satu peserta didik yang mendapatkan nilai terendah dikarenakan tidak hadir dalam beberapa pertemuan dalam pelaksaan siklus III. Sehingga peserta didik tersebut ketinggalan pelajaran dibandingkan teman-temannya yang lain dan kesulitan dalam menerapkan materi untuk menyelesaikan soal yang diberikan. Pada tes siklus III nilai ratarata peserta didik mencapai nilai KKM, dan persentase ketuntasan belajar klasikal telah memenuhi syarat sehingga tindakan pembelajaran dihentikan pada siklus III.

\section{SIMPULAN}

Penerapan model Mastery Learning berbantuan LKPD dapat meningkatkan hasil belajar matematika peserta didik di Kelas VIII.3 SMP Negeri 4 Kota Bengkulu dengan cara sebagai berikut:

a. Penjelasan materi kepada peserta didik dilakukan dengan mengaitkan materi yang dipelajari dengan kehidupan sehari-hari sehingga lebih mudah dipahami.

b. Peserta didik diminta untuk bertanya jika mengalami kesulitan dalam mengerjakan latihan soal yang diberikan.

c. Peserta didik diberikan bimbingan dalam mengerjakan latihan terstruktur dan latihan terbimbing, agar peserta didik mampu mengerjakan latihan mandiri meskipun tanpa bimbingan guru.

Nilai rata-rata hasil belajar peserta didik pada siklus I adalah 66,21 dengan persentase ketuntasan belajar $42,86 \%$, pada siklus II yaitu 79,14 dengan persentase ketuntasan belajar $68,57 \%$, dan pada siklus III yaitu 89,50 dengan persentase ketuntasan belajar 91,43\%.

\section{SARAN}

Berdasarkan penelitian yang telah dilaksanakan, terdapat beberapa saran yang dapat diberikan sebagai berikut:

1. Petunjuk kegiatan dalam LKPD harus jelas dan mudah dipahami agar alat peraga dapat dipergunakan dengan baik oleh peserta didik.

2. Guru memperhatikan urutan tahap kegiatan dengan model Mastery Learning disesuaikan alokasi waktu yang telah ditentukan dengan proporsi waktu untuk tahap penyajian $25 \%$, tahap latihan terstruktur 25\%, dan tahap latihan terbimbing $18 \%$. Sisa waktu yang tersedia digunakan untuk kegiatan pendahuluan, tahap orientasi, tahap latihan mandiri, dan kegiatan penutup.

3. Menyiapkan latihan-latihan soal dengan jumlah yang tidak terlalu banyak (cukup 2 soal) untuk setiap latihan yang diberikan 
serta disesuaikan tingkat kesulitannya agar pemahaman peserta didik dapat tercapai dan dapat belajar secara tuntas serta alokasi waktu yang diberikan bisa dipergunakan dengan tepat.

\section{DAFTAR PUSTAKA}

Aqib, Zainal, dkk. 2014. Penelitian Tindakan Kelas untuk Guru SD, SLB dan TK. Bandung: Yrama Widya.

Departemen Pendidikan Nasional. 2008. Panduan Pengembangan Bahan Ajar. Jakarta: Departemen Pendidikan Nasional.

Dimyati dan Mudjiono. 2006. Belajar dan Pembelajaran. Jakarta: Rineka Cipta

Hudojo, Herman. 2005. Pengembangan Kurikulum dan Pembelajaran Matematika. Malang: Universitas Negeri Malang.

Kunandar. 2011. Langkah Mudah Penelitian Tindakan Kelas Sebagai Pengembangan Profesi Guru Edisi Revisi. Jakarta: Rajawali Pers.

Maharani, Ervina. 2014. Panduan Sukses Menulis Penelitian Tindakan Kelas yang Simpel, Cepat dan Memikat. Yogyakarta: PARASMU.
Majid, Abdul. 2012. Perencanaan Pembelajaran Mengembangkan Standar Kompetensi Guru. Bandung: Remaja Rosdakarya.

Mulyasa, E. 2009. Kurikulum yang Disempurnakan; Pengembangan Standar Kompetensi dan Kompetensi Dasar. Bandung : Remaja Rosdakarya.

Prastowo, Andi. 2013. Panduan Kreatif Membuat Bahan Ajar Inovatif. Yogyakarta: Diva Press.

Sudjana, Nana. 2011. Penilaian Hasil Proses Belajar Mengajar. Bandung: Remaja Rosdakarya.

Sulastri. 2014. Pembelajaran Muatan Lokal Pendidikan Lingkungan Hidup dengan Model Pembelajaran Group Investigation untuk SMA/MA. Probolinggo: Jurnal Pendidikan Sains.

Surjadi. 2012. Membuat Siswa Aktif Belajar (73 Cara Belajar Mengajar dalam Kelompok). Bandung: Mandar Maju.

Trianto. 2011. Mendesain Model Pembelajaran Inovatif-Progresif. Jakarta: Kencana.

Wena, Made. 2009. Strategi Pembelajaran Inovatif Kontemporer; Suatu Tinjauan Konseptual Operasional. Jakarta: Bumi Aksara. 